Janusz ROPSKI

KEN Pedagogical University of Krakow

Institute of Security Sciences

janusz.ropski@up.krakow.pl

ORCID 0000- 0003-2750-4463

https://doi.org/10.34739/dsd.2020.02.11

\title{
INTERPERSONAL SECURITY IN SOCIAL INTERACTIONS
}

\begin{abstract}
Nowadays interpersonal safety in social interactions is becoming increasingly significant. Words and phrases such as hatred, hate speech, discrimination, contempt, verbal aggression, and bias-motivated crimes have been constantly present in our daily life and public discussions, which led to the new forms of social pathology. These phenomena pose a considerable danger to the social continuity, especially to the constantly evolving democracy in Poland. The main aim of the article is to attract the reader's attention to the danger triggered by verbal aggression, which has a detrimental impact on people's safety and their interactions in different spheres of social life.
\end{abstract}

KEYWORDS: interpersonal security, hate speech, discrimination, social interactions

\section{BEZPIECZEŃSTWO INTERPERSONALNE W RELACJACH SPOLECZNYCH}

\begin{abstract}
ABSTRAKT: Bezpieczeństwo interpersonalne w relacjach społecznych nabiera w dzisiejszych czasach szczególnego znaczenia. Nienawiść, mowa nienawiści, dyskryminacja, pogarda, agresja werbalna czy przestępstwa z nienawiści to słowa, które nieustannie pojawiają się w naszym życiu i dyskursie publicznym, przybierając postać nowej patologii społecznej. Są to zjawiska, które w chwili obecnej stanowią bardzo poważne zagrożenia dla trwałości społeczeństwa obywatelskiego, a przede wszystkim dla ciągle kształtującej się demokracji w naszym kraju. Głównym celem artykułu jest zwrócenie uwagi czytelnika na zagrożenia, jakie niesie za sobą agresja werbalna dla poczucia bezpieczeństwa człowieka i jego relacji interpersonalnych występujących w różnych dziedzinach życia społecznego.
\end{abstract}

SŁOWA KLUCZOWE: bezpieczeństwo interpersonalne, mowa nienawiści, dyskryminacja, relacje społeczne

\section{INTRODUCTION}

Human beings are social animals. We need the presence of other people to live and develop. Such a presence helps us to live through different social situations. Some of them are pleasant and bring positive feelings, while others are the source of stress, anxiety, or sadness. Nevertheless, to some extent, they have an influence on our personality, future behavior in society, and our outlook on life. 
The purpose of communication is to exchange information, feelings, and meaning. Our ability to communicate, negotiate, and reach a compromise determines whether important and profound issues in our complicated life carry meaning ${ }^{1}$.

A social aspect of communication is defined as the process by which participants create and share information to achieve a common understanding. Such a process constitutes a dialogue, in which interlocutors take turns in playing the roles of senders and recipients of the message they communicate with each other. A correct understanding in the communication process is only possible thanks to realizing and imagining an interlocutor's reaction. However, communication skills are of major importance in this process ${ }^{2}$. Communication with the use of words, gestures, symbols, language metaphors, or complex emotions is primarily the result of a long journey people had to undertake to adjust to the virtual reality that we see nowadays. Problems related to proper interpersonal communication usually appear when people start or maintain their relations, which is applicable to both workplace and families as well as many different places, where information can be misunderstood.

The paper is an attempt to apply the scientific approach to interpersonal security through the social relations an individual develops. Thus, the main research problem is the question: What the most important phenomena in nowadays interpersonal relations and communication, which can be observed and defined, particularly threaten social relations?

The Author assumes that problems such as discrimination, verbal aggression, hate speech, or contempt spech will have a negative effect and destructive impact on ongoing discourse and social dialogue.

\section{SOCIAL COMMUNICATION IN CONTEMPORARY WORLD}

These days interpersonal communication determines a standard for an individual to manage in the society by means of using multidimensional skills to communicate with people for diverse purposes. One of the most important ones is expressing feelings in such a manner that a recipient can understand the intended message. Thanks to appropriately chosen words, people can agree on certain issues or introduce changes to their behavior. In many cases, people use communication to make orders, or more often, to start relationships and form social bonds with people. It also plays a major role in communicating in a specific environment ${ }^{3}$.

An individual who wants to achieve satisfactory social relations should have the right knowledge and skills in this area. There are concrete norms created in different environments and social groups, which aim at determining the rules of proper behavior in particular groups. Communication in different situations serves as a filter of certain types of behavior.

\footnotetext{
${ }^{1}$ J. Ropski, Integrative function of teacher's communications skills, [in:] A. Karpińska (ed.), Education of "deeper lover" in dialogue and perspective, Białystok 2005, p. 295.

${ }^{2}$ J. Ropski, Communication skills of a future teacher, [in:] J. Kuźma, J. Morbitzer (ed.), Education - school teachers. Promoting child development, Krakow 2005, pp. 317-320.

${ }^{3}$ B. Jamrożek, J. Sobczak, Interpersonal communication, Poznań 2000, p. 21.
} 
Interpersonal interactions depend on creating such a situation that emotional involvement can be connected to the intellectual one between interlocutors of the communication process.

The most important interpersonal skills include:

- getting to know each other, perceiving, communicating, and understanding each other;

- helping and making a positive impact, especially enduring a sense of fear and threat in social relations;

- solving mutual problems and interpersonal conflicts in a creative manner;

- building a team to jointly carry out the assigned tasks;

- avoiding unnecessary conflicts and misunderstandings ${ }^{4}$.

Undeniably, such aspects are primarily important because the social and dynamical features of interpersonal competencies are the most crucial. The world around us is constantly evolving, enforcing continuous improvement, especially when interlocutors express different attitudes and behavior types.

\section{INTERPERSONAL SAFETY}

People live in their individual worlds, which are made up of knowledge, values, interpretation patterns, constructions of reality, and priorities. However, the surrounding world is full of hatred, loneliness, and increasingly often, deception is becoming a social norm. We are not able to survive on the physical, spiritual, or social level without forming true, honest, and satisfactory interpersonal relationships. For good and for bad, we are predestined to talk to each other even if the conversations have a double meaning or they are filled with violence and hate speech.

The history of humanity is also a history of aggression and violence, which can be also found in contemporary times. Despite many efforts to combat brutality, evil seems to be inherent. People tend to behave in an antisocial and intolerant manner.

Interpersonal safety in social communication is defined by the process in which participants create and share information to achieve a common understanding. Such a process constitutes a dialogue, in which interlocutors take turns in playing the roles of senders and recipients of the message they communicate with each other. A correct understanding of the communication process is only possible thanks to realizing and imagining an interlocutor's reaction. One of the most frequent examples of the threat to interpersonal interactions are phenomena such as discrimination and hate speech.

\section{DISCRIMINATION}

In the common sense, discrimination means differentiation - discrimination entails unfair and less favorable treatment due to some distinctive features that are not dependent on objective factors. It is derived from prejudices based on stereotypes of a certain group of people that are characterized

\footnotetext{
${ }^{4}$ J. Ropski, Education, Katowice 2015, p. 220.
} 
by a common attribute such as gender, origin, nationality, religion or belief, worldview, political view, disability, age, sexual orientation, marital status, or family background ${ }^{5}$.

Discrimination is predominantly reflected in imposing restrictions or not allowing some people or groups to get involved in the work of authorities. At times, discriminated people cannot get permissions that are accessible to others or it is impossible for them to attain some goods or values regarded as precious in a given culture ${ }^{6}$. In this sense, discrimination always has a social and cultural nature given that its definition is based on the criteria, interpretations, and opinions specified by cultural and social norms.

The legal basis for protection against discrimination in the Polish legal system is provided by the Constitution of the Republic of Poland of April 2, 1997 in Article 32, which reads as follows:

1. "All are equal before the law. Everyone has the right to equal treatment by public authorities.

2. Nobody may be discriminated against in political, social, or economic aspects for any reason"7.

Article 33 also mentions that gender equality shall be guaranteed:

1. "A woman and a man in the Republic of Poland have equal rights in family, political, social, and economic aspects.

2. In particular, men and women have equal rights to education, employment, and promotion, to receive equal pay for work of equal value, to social security and to hold positions, perform functions, and obtain public dignity and rewards." ${ }^{\text {. }}$

The principle of equality has been also reflected in European law documents from the beginning of the integration process. The approach of the authors towards this principle has been evolving together with social changes, which occurred in societies that created increasingly communities. The law that was created constituted the answer to the current changes regarding legal bases that regulate social relations and determine the core values of other supranational structures.

Factors that influence the evolution of changes in the treaties, which imply strengthening the standard of equality and legal protection against discrimination, can be divided into internal ones, developed by the member states, as well as external ones that have their sources beyond those communities.

At first, the only integration issue, in the broadly understood notion of equality and protection against discrimination, was equality between men and women, especially in the aspect of employment and their occupations. However, in the first three decades of the development of communities, these issues were perceived in a very narrow sense - in contrast

\footnotetext{
${ }^{5}$ K. Bogatko, A, Drabarz, K. Śmiszek, Against discrimination. Legal guide, Warszawa 2013, p. 4.

${ }^{6}$ B. Rysz-Kolwalczyk (ed.), Lexicon of social policy, Warszawa 2001, p. 38.

${ }^{7}$ Constitution of the Republic of Poland of April 2, 1997, Journal of Laws of 1997, No. 78 item 483.

${ }^{8}$ Ibidem.
} 
to the current comprehensive and horizontal set of actions to guarantee equal opportunities for men and women and the principle of gender equality in both formal and material terms ${ }^{9}$.

\section{LAW AND DISCRIMINATION}

The fundamental legal acts, which aim at ensuring the compliance with the indicated constitutional norms and performance of obligations related to the implementation of European Union directives into the domestic legal order, include the Act of 3 December 2010 on the implementation of certain European Union provisions regarding equal treatment ${ }^{10}$.

This Act defines the areas and ways of preventing violations of the principle of equal treatment on the grounds of sex, race, ethnicity, nationality, religion, belief, disability, age, or sexual orientation.

The term used in the Act concerning the implementation of certain European Union regulations covers equal treatment ${ }^{11}$ :

a. direct discrimination - is understood as a situation in which a natural person due to sex, race, ethnicity, nationality, religion, belief, disability, age, or sexual orientation is treated less favorably than another person in a comparable situation

b. indirect discrimination - is understood as a situation in which for a natural person due to sex, race, ethnicity, nationality, religion, belief, disability, age, or sexual orientation may experience an adverse disproportion or a particularly unfavorable situation as a result of a seemingly neutral provision, unless the provision, criterion, or action is objectively justified owing to the legitimate aim to be achieved and the means to achieve this are appropriate and necessary

c. harassment - it means any undesirable behavior, whose purpose or effect is to violate the dignity of a natural person and to create an intimidating, hostile, degrading, humiliating, or derogatory atmosphere

d. sexual harassment - it means any undesirable sexual behavior toward a natural person or relating to sex, the purpose or effect of which is to violate the person's dignity, in particular by creating an intimidating, hostile, degrading, humiliating, or derogatory atmosphere; this behavior may consist of physical, verbal or non-verbal elements

e. unequal treatment - it means treating a natural person in one or more of the following: direct discrimination, indirect discrimination, harassment, sexual harassment, and less favorable treatment of a natural person resulting from the rejection of harassment or sexual harassment or submission harassment or sexual harassment, and encouraging and demanding such behavior from others

\footnotetext{
${ }^{9} \mathrm{~K}$. Śmiszek (ed.), The EU prohibition of discrimination in the light of Polish law. Analysis of anti-discrimination regulations in the practice of Polish courts, Warszawa 2018, p. 9.

${ }^{10}$ Act of 3 December 2010 on the implementation of certain EU provisions concerning equal treatment, Journal of Laws of 2010, No. 254 item 1700.

${ }^{11}$ Ibidem, pp. 2 -3.
} 
f. the principle of equal treatment - it means the absence of any behavior that could be regarded as unequal treatment

g. services - it means services within the scope of Article 57 of the Treaty on the Functioning of the European Union ${ }^{12}$.

Discrimination as a multidimensional and complex phenomenon can take many forms. There are several typologies of discrimination in the literature given its nature and broad scope. The first division concerns the distinction between direct and indirect discrimination. The former is understood as intended and organized activities that aim at limiting or denying access to means that satisfy human needs or positions which allow to obtain them.

In this case, unequal behavior is defined as an indirect consequence of decisions made solely on the basis of a discrediting attribute (e.g., unfavorable decisions made on the grounds of ethnicity, gender, or age of an individual). Indirect discrimination occurs when certain activities have a discriminatory consequence, even though it was not intended ${ }^{13}$.

Famous Polish sociologist Piotr Sztompka draws attention to the scope of discrimination regarding an opportunity to change a social status (social mobility). He distinguishes multiple situations. Complete discrimination occurs when a person or group has no chance for social promotion, whereas partial discrimination has various forms: deprivation of the possibility of promotion of representatives of a given group to the highest positions in a given hierarchy by creating a ceiling, above which they are not able to enter (the so-called glass ceiling), occupational segregation or restrictions, or closure of certain social mobility channels (e.g., restricted access to education $)^{14}$.

The situation described above is frequently related to hierarchical, professional groups such as the army or police, in which formal regulations or reluctance of superiors do not allow for the change of a professional position of the personnel corps.

\section{HATE SPEECH}

I am inclined to believe that these days we have to be particularly aware of a relatively new type of threat to social relations, that is hate speech, which is becoming a new social pathology. Hate speech is one of the most serious threats to the continuity of the society and, above all, it is dangerous to constantly evolving democracy. It is a hazardous live tool used not only by social media users, but also by politicians or people who want to influence social interactions and a sense of security of regular citizens. Furthermore, haters and hate speech users have a feeling of impunity, which is provided by contemporary political elites. This immensely negative phenomenon has spread in Poland in recent years and it can have adverse

\footnotetext{
${ }^{12}$ Services defined in the Treaties are those that are normally provided for remuneration to the extent that they are not covered by the provisions on the free movement of goods, capital, and individuals. In particular, services include industrial, commercial, and craft activities as well as legal professionals.

${ }^{13}$ B. Rysz-Kolwalczyk, op.cit. p. 38.

${ }^{14}$ P. Sztompka, Sociology. Analysis of the society, Kraków 2002, p. 343.
} 
consequences, especially on young people who are prone to such an aggressive and suggestive impact. It is demonstrated by numerous sociological research ${ }^{15}$, which prove that a substantial majority of citizens clearly declare having some experience with hate speech daily.

Language, which we use every day, shapes social consciousness. Words bring quality, evaluation, and value to things. By giving names, we create the reality which only exists if it is described. That is why the way we describe the world ${ }^{16}$.

Language is the main tool for representatives of many professions, which means we have to take care of it and constantly improve. It is obligatory for teachers, lawyers, journalists, soldiers, policemen, or politicians to speak Polish fluently to perform work effectively.

The observation of the speech tendencies of contemporary Poles allows for the conclusion that there is still room for improvement in terms of language competencies among different professions. There are no institutionalized forms of teaching the use of the mother tongue to adults. There is also an insufficient number of dissertations that address the need for self-education of specific environments or professional groups, e.g., priests, officials, and lawyers ${ }^{17}$.

Hate speech mostly applies to spoken and written expressions (articles, online content, comments), drawings, graphics, musical works, which offend, falsely accuse, lie, and humiliate individuals or groups because of their race, origins, religion as well as gender, sexual orientation, and disability.

The phenomenon of migration that is taking place in contemporary Europe, in particular of intercultural nature, causes an increase in radical and extremist moods in many societies as well as in Poland. Nationalist, chauvinist, xenophobic, and even anti-Semitic, racist, and neoNazi ideas are often propagated. Hatred is often triggered by national, ethnic, racial, or religious differences between people. It is also easy to observe that such groups of people or individuals experience verbal and physical aggression.

Hate speech is usually accompanied by negative and extremely unfavorable, or even hostile feelings against those individuals or groups. Hate speech appears as a component of wider social phenomena such as anti-Semitism, xenophobia, racism, homophobia, or transphobia (negative attitudes toward transsexual and transgender people ${ }^{18}$ ).

To better understand the essence of this semantic category, it is worth quoting the definition of hatred from the Polish Dictionary edited by M. Szymczak: "hatred is a feeling of strong resentment and hostility toward someone or something"19.

Most frequently, hate speech is directed against the following social minorities: Jews, Muslims, refugees, Romanian, Ukrainian, black people, gays, lesbians, transsexual people, feminists. Most

\footnotetext{
${ }^{15}$ M. Bilewicz, M. Marchlewska, W. Soral, M. Winiewski, Hate speech. Survey report, Warszawa 2014.

${ }^{16}$ R. Biedron, Introduction to the report, [in:] G. Czarnecki (ed.), Report on homophobic hate speech in Poland, Warszawa 2009, p. 7.

${ }^{17}$ M. Malinowski, Polish language. Greater linguistic correctness of legal texts and others (from the preface by Professor M. Mycawki), Kraków 2018, p. 11.

${ }^{18}$ D. Wutke, Hate speech. Guide for organizations of non-governmental activists, Warszawa 2016, p. 9.

${ }^{19}$ M. Szymczak (ed.), Polish Dictionary, volume 2, Warszawa 1988, p. 342.
} 
importantly - the range of victims of hate speech is expanding at a dangerous speed. In the past, mostly the representatives of minorities were affected. These days, it can be anyone who, according to a potential perpetrator, does not fit into the "social frames" defined by the majority of the society. Those can be people that represent specific views, professional groups (e.g. policemen), and they speak a specific language or dialect (e.g., Silesians) ${ }^{20}$.

A major role in the formulation of hate speech is played by secondary prejudice, that is perceiving a given group as deserving bad treatment due to their previous harmful behavior.

Researchers that deal with this issue in Poland came to the conclusion that what is known as "hate speech" stems from contempt rather than hatred. Prior assumptions about the discussed phenomena proved right. It should be renamed to "contempt speech" because it is built on humiliation that blocks any empathetic reactions and objectifies another person ${ }^{21}$.

Nowadays, verbal aggression is a universal phenomenon, which covers all social environments and age groups, and it is becoming an increasingly accepted form of aggression in social communication.

Communication within various online forums poses a substantial threat to shaping proper social relations. It is worth highlighting the fact that the problem of hate speech in the media, including the Internet, applies not only to online forums. Although anonymity allows for the use of the language of hostility, similar content can be found on social networks, in newspaper articles and $\mathrm{TV}$ or radio programs, and social campaigns, which are also becoming the target of attacks.

The language of hostility is a similar, but not entirely identical concept. Unlike hate speech, it does not generate a coherent image of the enemy, but uses associations, understatements, or metaphors, which emphasize negative and falsely recognized features of the opponent ${ }^{22}$.

\section{DEFENSE AGAINST HATRED}

It is challenging to defense oneself against hate speech, hostility, and contempt because of a convenient and abused argument stating the right to freedom of expression, which is associated with a lack of responsibility for one's words and disrespect for others' feelings. Distancing, which is typical of Internet communication, and the lack of direct contact between users create the illusion that wounds inflicted by words do not really hurt ${ }^{23}$.

This argument is not only used by different groups of nationalists and extremists, but also by a number of lawyers, including prosecutors and judges, who do not proceed with prosecution for racist and xenophobic statements.

\footnotetext{
${ }^{20}$ G. Bah, Police response to hate speech in public space, [in:] M. Gumkowski, Forms of discrimination and methods of combating it. Law enforcement guide, Warszawa 2015, p. 18.

${ }^{21}$ M. Winiewski, K. Hansen, M. Bilewicz, W. Soral, A. Świderska, D. Bulska, Hate speech. Contempt speech. Report on the study of verbal violence against minority groups, Warszawa 2017, p. 9.

${ }^{22}$ A. Naruszewicz-Duchlińska, Hatred in the times of the Internet, Gdynia 2015, p. 17.

${ }^{23}$ Therein, p. 182.
} 
Yet, we cannot follow the false conviction that people who offend others can feel completely innocent because the fight against hate speech in Poland is enabled both by civil and criminal law.

Civil Law: Article $24 \S 1$ of the Civil Code says: "Everyone whose personal wellbeing is threatened by someone else's actions may demand this action to be discontinued, unless it is not unlawful. In the event of a breach, the person may also require that the person who committed the breach should complete the steps needed to remove its effects, in particular that the person makes a statement of the appropriate content and in the appropriate form. In accordance with the principles provided for in the code, the person may also demand monetary compensation or payment of an appropriate sum of money for a given social purpose ${ }^{24}$ ".

Criminal Law: Article $119 \S 1$ - according to the Penal Code: “Anyone who uses violence or an unlawful threat against a group of people or an individual because of their nationality, ethnicity, race, politics, religion, or because of one's lack of faith, shall be punished by imprisonment from 3 months to 5 years ${ }^{25}$ ".

The most important international regulations for fighting against hate speech are:

- Article 20 - International Covenant on Civil and Political Rights

- Article 4 - International Convention on the Elimination of all Forms of Racial Discrimination

- Article 3 - Convention on the Prevention and Punishment of the Crime of Genocide

- Article 17 - European Convention for the Protection of Human Rights and Fundamental Freedoms

- Article 4-Charter of Fundamental Rights

- Additional Protocol to the Council of Europe Convention on Cybercrime on Criminalization of Racist or Xenophobic Acts Committed Using Computer Systems

- Council Framework Decision 2008/913/JHA of 28 November 2008 on combating certain forms and expressions of racism and xenophobia by means of criminal law.

\section{CONCLUSIONS}

Behaviors such as discrimination and hate speech are normally derived from stereotypes, prejudice, intolerance, discrimination, and extremist ideologies. Perceiving the world on the basis of stereotypes leads to prejudice against an individual or a social group because of their race, nationality, ethnicity, religion, or other innate or acquired features. Prejudices can translate into intolerance and discrimination of those social groups, and they can even lead to social exclusion.

Interpersonal safety in social interactions is regarded as the process or the process result, in which participants follow and spread some information to reach a common understanding. The most frequent examples of the threat to social relations are phenomena such as:

\footnotetext{
${ }^{24}$ Act of 23 April 1964 Civil Code, Journal of Laws of 2019, item 1145, Article $24 \S 1$.

25 The Act of June 6, 1997, Penal Code, Journal of Laws of 2019, item 1950, Article $119 \S 1$.
} 
discrimination, verbal aggression, hate speech, or contempt speech. Those social phenomena have been increasingly growing in recent years. They bring dangerous consequences, especially for young people who are prone to such aggressive and suggestive behavior.

The Author believes that the methodological aim of the paper has been met and the substantive content will be a base for further scientific analysis and discussion on the sense of security of partners in dialogue and social discourse.

\section{BIBLIOGRAPHY}

Bah Gerard. 2015. Police response to hate speech in public space. W Gumkowski Marek, Forms of discrimination and methods of combating it. Law enforcement guide. Warszawa. Wyd. Bell Studio. pp. 17-26.

Biedroń Robert. 2009. Introduction to the report. W Czarnecki Greg (ed.), Report on homophobic hate speech in Poland. Warszawa. Kampania Przeciw Homofobii.

Bilewicz Michał, Marchlewska Marta, Soral Wiktor, Winiewski Mikołaj. 2014. Hate speech. Survey report. Warszawa. Fundacja im. S. Batorego.

Bogatko Katarzyna, Drabarz Anna, Śmiszek Krzysztof. 2013. Against discrimination. Legal guide, Warszawa. Fundacja Fundusz Współpracy.

Jamrożek Bożena, Sobczak Jolanta, Interpersonal communication. 2000. Poznań. eMPi2.

Malinowski Maciej, Polish language. Greater linguistic correctness of legal texts and others. 2018. Kraków. Ekodruk s.c.

Naruszewicz-Duchlińska Alina, Hatred in the times of the Internet. 2015. Gdynia. Novae Res.

Ropski Janusz. 2015. Education for safety in Polish schools and the possibilities of improving it. Katowice. AWF.

Ropski Janusz. 2005. Integrative function of teacher's communication skills. W Karpińska Anna (ed.), Education of “deeper lover" in dialogue and perspective, Białystok. Trans Humana. pp. 295-303.

Ropski Janusz. 2005. Communication skills of a future teacher.. W Kuźma Józef, J. Morbitzer Janusz (ed.), Education - school - teachers. Promoting child development. Kraków. AP. pp. 317-321.

Rysz-Kolwalczyk Barbara (ed.). 2001. Lexicon of social policy. Warszawa. UW.

Sztompka Piotr, Sociology. Analysis of the society. 2002. Kraków. Znak.

Szymczak Mieczysław (ed.). 1988. Polish Dictionary, volume 2, Warszawa. Wyd. PWN.

Śmiszek Krzysztof (ed.). 2018. The EU prohibition of discrimination in the light of Polish law. Analysis of anti-discrimination regulations in the practice of Polish courts, Warszawa. PTPA. Winiewski Mikołaj, Hansen Karolina, Bilewicz Michał, Soral Wiktor, Świderska Aleksandra, Bulska Dominika. 2017. Hate speech. Contempt speech. Report on the study of verbal violence against minority groups. Warszawa. Fundacja im. Stefana Batorego.

Wutke Damian. 2016. Hate speech. Guide for organizations of non-governmental activists. Warszawa. Otwarta Rzeczypospolita.

ZHANG Li-Na. 2018. Importance of Interpersonal Skills at Work towards Managing People in an Educational Context, 2018 5th International Conference on Management Science and 
Management Innovation (MSMI 2018) [in] Advances in Economics, Business and Management Research (AEBMR), volume 54, pp. 29-34.

\section{LEgaL ACTS}

Constitution of the Republic of Poland of April 2, 1997, Journal of Laws of 1997, No. 78 item 483. Act of 23 April 1964 Civil Code, Journal of Laws of 2019, item 1145, Article $24 \S 1$.

Act of 3 December 2010 on the implementation of certain European Union provisions concerning equal treatment, Journal of Laws of 2010, No. 254 item 1700.

The Act of June 6, 1997, the Penal Code, Journal of Laws of 2019, item 1950, Article $119 \S 1$. ECRI General Policy Recommendation No. 15 on Combating Hate Speech Adopted on 8 December 2015, European Commission Against Racism And Intolerance (ECRI) Council of Europe - 2016 Printed in Strasbourg. 